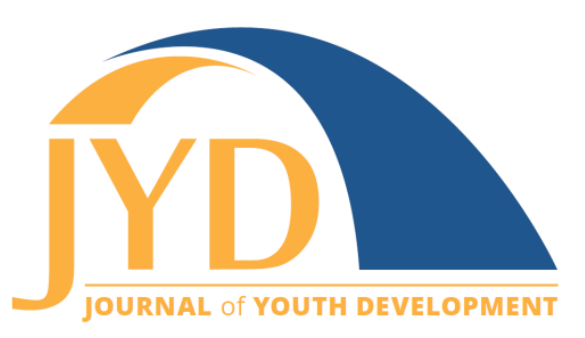

http://jyd. pitt. edu/ | Vol. 14 Issue 4 DOI 10.5195/jyd.2019.846 | ISSN 2325-4017 (online)

\title{
Book Review-Reclaiming Community: Race and the Uncertain Future of Youth Work
}

\section{Ishmael A. Miller}

University of Washington, Seattle

milleri@uw.edu

\begin{abstract}
Reclaiming Community: Race and the Uncertain Future of Youth Work (Baldridge, 2019) presents a case study of a community-based after-school organization that supports youth cultural, identity, academic, and political development. This book highlights the organization as it tries to navigate neoliberal educational reforms.
\end{abstract}

Key words: after-school program, youth workers, youth development, community-based organization

Bianca Baldridge has been an assistant professor in the Department of Educational Policy Studies at the University of Wisconsin, Madison, since 2013. Baldridge is a prodigious voice in the field of community-based youth education, having produced several referred articles, book chapters, technical reports, and scholarly presentations. Baldridge is a former youth worker turned critical scholar who explores the organizational and pedagogical practices of youth workers at community-based organizations. She was trained in the sociology of education and uses that knowledge to apply critical theories to the growing neoliberal restructuring of educational spaces. Neoliberalism asserts market-based reforms, such as privatization, standardization, and accountability measures are the most efficient means of increasing educational outcomes such as student academic performance (Apple, 2004). Baldridge views neoliberal restructuring of education as subtractive to communities of color as it frames them with deficit rhetoric and ignores the assets they bring to educational spaces (Baldrige, 2014).

(c) EY Ev articles in this journal are licensed under a Creative Commons Attribution 4.0 License. This journal is published by the University Library System, University of Pittsburgh and is cosponsored by the University of Pittsburgh Press. The Journal of Youth Development is the official peer-reviewed publication of the National Association of Extension 4-H Agents and the National AfterSchool Association. 


\section{Book Review-Reclaiming Community}

Reclaiming Community: Race and the Uncertain Future of Youth Work (Baldridge, 2019) is a case study about Educational Excellence $(E E)^{1}$, a community-based after-school organization. The purpose of this book was to demonstrate how EE's youth workers navigated political forces that are pushing "market-based approaches to public education, education restructuring aligned with deep privatization, and racialized paternalism" (p. 7). The case of EE is indicative of larger narratives within educational organizations that face neoliberal reforms that threaten the positive development of youth of color. Reclaiming Community: Race and the Uncertain Future of Youth Work provides a needed example of how youth workers both challenge and reproduce racial disparities in a community-based after-school organization as they "navigate complex economic, social, and political barriers in their work with young people" (p. 13).

The book is organized into two sections with three chapters in each segment. Section 1 is titled "The Golden Era" and focuses on the 10-year period when EE was led by Executive Director Leah Davis ${ }^{2}$ (a Black woman). Under Davis's leadership EE focused on holistic youth development marked by high expectations in academics and cultural identity development. Section one highlights examples of culturally responsive leadership typified by crafting a learning environment that is inclusive and supportive of ethnically and culturally diverse youth (Johnson, 2006; Khalifa, Gooden, \& Davis 2016). Baldridge framed EE as upholding and sustaining "cultural and pedagogical practices rooted in identity affirmation; high expectations; and authentic relationships of radical care between staff and students" (p. 202). Additionally, Davis was a noted defender against deficit pathologizing and neoliberal reforms of the board of trustees' chair Richard Dunn ${ }^{3}$. A strength of the first section is that Baldrige demonstrates tensions that occurred at EE, which Parker \& Villalpando (2007) believe helps the reader to develop a more "layered" understanding of educational organizations. EE had contradictions that reified White normativity, such as upholding respectability politics against various forms of youth culture including forms of dress. However, Baldridge believed EE was a "fugitive space" (p. 5) despite these challenges, where students can escape oppressive structures of antiBlackness.

The second section titled "Things Fall Apart" focuses on the leadership of Executive Director Gina Roy (a White woman). Roy was named Executive Director soon after Davis, and her

\footnotetext{
${ }^{1}$ Pseudonym

2 Pseudonym

3 Pseudonym

${ }^{4}$ Pseudonym
} 


\section{Book Review-Reclaiming Community}

leadership was typified by eroding EE's past organizational values. EE became "business-like," pursuing market-based objectives such as increasing student academic scores and expanding the number of youths served, rather than providing cultural development and radical care between staff and students. Baldridge writes that Roy's approach "jeopardized the organization's comprehensive approach and intimate relationship building between staff and students" (p. 203) because she did not have a proper understanding of the organizational culture and strengths. The failures of EE under Roy demonstrate how market-based reforms create tensions that are antithetical to creating an organizational philosophy that values cultural pluralism.

Reclaiming Community: Race and the Uncertain Future of Youth Work is a rigorous ethnographic case study built on research conducted from 2011-2015. Baldridge conducted numerous interviews, focus groups, surveys, and document analyses. The prose is rich with firsthand examples of the triumphs and tensions that EE youth workers were navigating, making the book an easy read. Baldridge does the additional work of adding an appendix where she discusses her researcher positionality to better inform the reader of the joy and tensions she encountered while completing this study. This discussion is a valuable contribution to the work, as Banks (1998) suggests that researchers must understand and make explicit our journey and values to approach objectivity.

An increasingly important theme researchers have examined in community-based youth education is the need for increased cultural competency for youth workers (Toldson \& Lemmons, 2015; Woodland, 2008). The book is adept at examining practices that are both culturally relevant and sustaining, while critiquing neoliberal reforms. In addition, the book has diverse applicability to non-profit management, exploring organizational culture, strategic planning, and navigating board relations. This book is a resource that will provide powerful insights to both researchers and practitioners as they pursue creating dynamic educational institutions for youth of color.

\section{References}

Apple, M. W. (2004). Creating difference: Neo-liberalism, neo-conservatism and the politics of educational reform. Educational Policy, 18(1), 12-44. doi:10.1177/0895904803260022

Baldridge, B. J. (2014). Relocating the deficit: Reimagining Black youth in neoliberal times. American Educational Research Journal, 51(3), 440-472. doi:10.3102/0002831214532514 
Journal of Youth Development | http://jyd.pitt.edu/ | Vol. 14 Issue 4 DOI 10.5195/jyd.2019.846

\section{Book Review-Reclaiming Community}

Baldridge, B. J. (2019). Reclaiming community: Race and the uncertain future of youth work. Redwood City, CA: Stanford University Press.

Banks, J. A. (1998). The lives and values of researchers: Implications for educating citizens in a multicultural society. Educational Researcher, 277), 4-17. doi:10.3102/0013189X027007004

Johnson, L. (2006). "Making her community a better place to live": Culturally responsive urban school leadership in historical context. Leadership and Policy in Schools, 5, 19-36. doi:10.1080/15700760500484019

Khalifa, M. A., Gooden, M. A., \& Davis, J. E. (2016). Culturally responsive school leadership: A synthesis of the literature. Review of Educational Research, 86(4), 1272-1311. doi:10.3102/0034654316630383

Parker, L., \& Villalpando, O. (2007). A race(cialized) perspective on education leadership: Critical race theory in educational administration. Educational Administration Quarterly, 43(5), 519-524. doi:10.1177/0013161X07307795

Toldson, I. A., \& Lemmons, B. P. (2015). Out-of-school time and African American students: Linking concept to practice (editor's commentary). The Journal of Negro Education, 84(3), 207-210. doi:10.7709/jnegroeducation.84.3.0207

Woodland, M. H. (2008). Whatcha doin' after school? A review of the literature on the influence of afterschool programs on young Black males. Urban Education, 43(5), 537-560.

doi:10.1177/0042085907311808 